\title{
Crowdfunding and smes funding in nigeria-pros and cons
}

\author{
Ajayi Olalekan Ezekiel, Oyedele Toba \\ lekzyplus@yahoo.com \\ Department Of Business Administration, Faculty of Management Science Ajayi Crowther \\ University Oyo, Oyo State Nigeria \\ Department Of Accounting and Finance, Kwara State University, Malete Kwara State
}

\begin{abstract}
Crowdfunding is a new layer of fundraising for small and medium-scale enterprises (SMEs) and other innovative ideas that offer an incentive to lift the power of the Internet from the crowd. As a new method of fundraising, the main knowledge of the idea is missing on the part of the entrepreneur, the financial professional, the academician, and the general public.

This calls for a deeper understanding of concepts, models, pros, cons; it is against this backdrop that the study looked at crowdfunding as alternative sources of financing for small and mediumscale enterprises

The study used an exploratory research approach with a focus on literature in the fields of Business Management, Accounting, and Finance, Internet academic journals, blogs, government publications and records, a variety of research reports and by individual researchers

The conclusion is that crowdfunding for small and medium-scale enterprises (SMEs) activities is a possibility in Nigeria and should be seen by people as an idea and a shift from negative thinking; of course, regulatory and other stakeholders have complementary roles to play.
\end{abstract}

Keywords -crowdfunding, internet, cons, pros, small and medium enterprises (SMEs) 


\section{INTRODUCTION}

Internet-aided crowdfunding is an emerging Financing innovation available to entrepreneurs and other Laudable creators of innovative business ideas for funding projects or creative ideas for agreed rewards. In recent times, global attention has been gained as an alternative means of financing start-up business and social development projects. It's a new and fast-growing form of finance Intermediation that channels funds from investors or savers or lenders to borrowers, individuals or businesses or share capital users (companies) without involving conventional financial institutions such as banks (EU, 2015). This financing process, which has more than 450 platforms worldwide, has become popular in developed economies such as Canada, USA, France, Britain, the Netherlands, China and India, Indonesia, Germany, Australia, Japan, but at a low level of use in Africa, particularly Nigeria for financing entrepreneurship.

It is a fund-raising technique via social media networks by showing details of facts, videos, and images about profitable and non-profitable business ideas or projects. This is an innovative funding tool for 21st-century digital innovation open to Small and Medium Enterprises (SMEs) and other social ventures such as the entertainment sector, donation of healthcare, and other small creative ideas. This is not only access to financing through SMEs but also as a way of providing a wider number of individuals access to investment opportunities. Mollick (2014), it is a form of fundraising through the internet from a large group of people without the involvement of any traditional intermediaries. Nordin, Ismael, and Zainuddin (2017) stated that the alternative means of bringing the dream of creative ideas and SMEs into fulfillment is by adopting crowdfunding.

These alternative means is because the entrepreneur faces various challenges of raising funds from banks for a start-up business, which is usually based on the selective and strict condition attached to such an application for loans. The stringent requirement for fund sourcing is one of these problems for SMEs, and this issue is one of the major constraints for the growth and development of SMEs. Sourcing fund issue through conventional sources needs alternative sources of funds for SMEs and this alternative source of funds is crowd financing. 
Crowdfunding is not a new form of fundraising, but the advent of technology has made the concept a new form of funding for small and medium-sized enterprises and creative ideas (Soreh 2017).

Wieck, Bretshneider, and Leimeister (2013) argued that Crowdfunding is an alternative fund source that allows small and medium-sized enterprises and other creative ideas to raise funds from the crowd by harnessing the power of the Internet to a start-up business. According to Fleming and Sorenson (2016), this is an alternative means of finance for start-up companies, since access to capital from the conventional financial institution has become difficult and strict. As a new form of the funding opportunity, there is a lack of knowledge on the part of the entrepreneur, the financial expert, the academician, and the general public.

Crowdfunding is different from other means of financing available to small and medium-sized enterprises. In a crowd-funding approach, small and medium-sized enterprises or project initiators approach the crowd-funding platform or website by introducing the intended project to interested parties or crowd-funders in the form of a listing. The necessary information on the project will be shown on the internet to interested crowd funders for decision-making. This allows the crowd funders to appraise the project to either support or not to support the ideas based on their perception. The potential investors or crowd funder formed an opinion on which investment to invest in based on investment opportunities available. The supporters of the project with financial commitment are regarded as a backer and are rewarded. The reward could be in form of monetary or material; or non-monetary or depending on the purpose of the campaign and backers perception of the projects (Agral, Catalini \& Goldfarb, 2014). There are three parties to crowdfunding; these are fund seekers, crowd investors, and internet platform operators, Trust is key to the success of crowdfunding which flows through the form of shared values or geographical boundaries. A double trust dilemma according to Hornuf and Schwienbarcher (2016) might arise when SMEs seek to fund from external sources through crowdfunding. This could likely involve the loss of creative ideas by SMEs to fund providers due to the release of valuable information in respect of such creative ideas or the projects to the general public which can be replicated and used by the potential investors. This issue of loss of creative ideas reduces the opportunity from using crowdfunding as a means of fundraising and also limits innovative project ideas. This means that only projects that will be difficult in replicating will be readily 
available for crowdfunding and also provided by SMEs for showcasing. In developed countries, a large number of SMEs had used a crowdfunding platform to the raised fund to start their businesses as it often provides a simple and faster access than the traditional method of financing. In these developed countries, various crowdfunding platforms had successfully aid fund seekers in raising funds for their business. In the USA, there are Indiegogo was established in 2008, and Kickstarter which commenced operation in 2009. In France, there is My Major Company which is the leading crowdfunding platform and it Commenced operation in 2007. Indiegogo in 2015 raised USD12milliion for Flow Hive in developing a project of a better way of harvesting honey without being disturbed or stung by bees. Kickstarter also in 2015 raised USD 20million for a project called Pebble Time Smartwatch. my major Company in France had also assisted young artists to raised funds for career development (Nordin, Md. Sum \& Zainuddin, 2018). SMEs occupy a pivotal position in economic development in terms of entrepreneurship development, employment generation, Gross Domestic Product (GDP) growth contribution, product diversification, market penetration, and forward integration with large scale industries. In Africa, crowdfunding is at a low level of awareness and its future expansion as an alternative financing option for SMEs is hindered by the low form of internet web operation, low social media usage, and a limited amount of fund that can be transferred through few approved payment options platforms in most African countries. The advantage of the crowdfunding concept had led some enterprises to embrace it which had led to the creation of several platforms in Africa likes Crowd Africa, Afrikstart, Thunda Fund, Start Me, Jumpstart Africa, Nigeria 234 Gives, and Fund Find Slice Biz. Afrikstart (2015) reported that there are 57 active crowdfunding platforms in Africa and these crowdfunding platforms jointly raised \$32.3 million in 2015 which is less than $0.1 \%$ of the world crowdfunding activities with South Africa being the leading country in this fundraising.

Besides, according to World Bank estimates in Foundy.com (2017), it was reported that the SubSahara Africa crowdfunding markets would be $\$ 300$ billion in 2025 . This would be achieved with South Africa leading the way in Africa crowdfunding platforms with 21 operational platforms and this is followed by Nigeria with 9 platforms. In respect of 57 active crowdfunding platforms in Africa, 9 were launched in 2012, while 17, 26, and 23 were launched in 2013, 2014, and 2015 respectively. As of 2015, the crowdfunding market in the continent had 21 donationbased platforms (37\%), 19 equity-based platforms (33\%), 13 reward-based platforms (23\%), 2 
peer to peer lending platforms (3.5\%), and 2 hybrid platforms (3.5\%). The donation and equitybased platforms are the fast-growing crowdfunding models in Africa. Crowdfunding in Africa has much focus on promoting fundraising for social causes, business and entrepreneur projects, creative and innovation projects with a relevant percentage of $31.5 \%, 21 \%$, and $17.5 \%$ of the total platforms respectively. In Nigeria, SMEs are faced with the problem of underperformance which could be attributed to poor funding which is paramount with other issues such as lack of access to technology, low managerial skill, un-conducive business environment, and lack of access to funding (Kazaure \& Abdullah, 2018). The inability of money deposit banks to mitigate the need for SMEs to fund had made innovative ideas not to see the light of day. In some cases, the problem of expansion and growth faces established SMEs by a promoter due to inadequate financing where necessary, thereby shortening the vital roles and contribution of such SMEs to the economy. SMEs are fundamental to the growth and prosperity of nationhood. This also boosts individual jobs by raising the rate of unemployment in the society. This also offers the forum for raising person migration to the cities from the rural geographic place. . Given these benefits, finance still posed a major challenge to SMEs as a vehicle of growth and development in an economy whereby lack of access to finance had led to some business closure (Gbandi \& Amissah, 2014).

In Nigeria's business environment, small and medium-sized enterprises have the highest number of business enterprises, accounting for more than $90 \%$ of enterprises. Although this contribution to the business environment makes a very low contribution to GDP of $1 \%$ due to poor funding, leading to additional problems such as lack of management expertise and access to modern technology (Kazaure \& Abdullah, 2018). In finding a solution to this problem, Agral, Catalini, and Goldfarb (2014) reported that the constraints experienced by SMEs and creative ideas in the search for the fund when required for purpose of growth and expansion, profit prospect, and increase in business market share can be resolved with the use of crowdfunding. Ariyo (2000) stated that the problems and challenges which SMEs and creative ideas initiators face in terms of raising finance could be attributed to their inability to recognize other sources of finance available for them to use. As the traditional and intended investors back out, coupled with nonintervention of finance from the government agencies and other financial assistance from elsewhere, SMEs and creative ideas initiators have no option than to tap into other means of fundraising. Therefore, using the crowdfunding platform to fill the gap created by the money 
deposit bank and other government agencies becomes inevitable to enhance the business operation of the SMEs. In the present day, crowdfunding is fast-growing and popular as an innovative internet-based platform for financing

Creativity ideas and new project (Suhaili \& Palil 2016) This enables an entrepreneur to source for the fund, contribution, donation, equity, or loan through internet platform from a group of individuals across the globe in financing creative ideas and start-up business (Yu, Johson, Lai, Cricelli \& Fleming, 2017).

The knowledge gap on the other sources of funding available to small and medium-sized enterprises in Nigeria has led this paper to focus on crowdfunding as an alternative form of finance, providing knowledge on crowdfunding for academics, small and medium-sized enterprises, and project initiators. According to Hossain (2015), crowdfunding is still scarce and sketches in literature, and as an entrepreneur's financial focus, it is not popular in developing countries like Nigeria. Only a few of the Crowd Funding studies have been conducted in developed countries. Najah and Jabu (2015) Studies have indicated that crowdfunding, like research, is less explored. This was collaborated by Mollick (2014) who stated that there is a lack of basic knowledge of Crowdfunding and therefore call for a better understanding of the concept, element, and environmental characteristics for entrepreneurs to implement and use it. Small companies face difficulties in accessing start-up capital from banks, as these banks are more selective and hesitant to offer loans to these business groups.

The objectives of the study are to outline and explain the concept of crowdfunding, to promote the use of crowdfunding as alternative sources for raising money for product development, expansion and growth, commercialization and financial stability for small and medium-sized enterprises in Nigeria, and to raise awareness among the general public, particularly among potential users of crowdfunding, crowdfunding seeking financial funding with the less stringent process as obtainable in money deposit bank, and to explore the importance of crowdfunding and how the concept operates compared to another traditional method of raising fund by the entrepreneur. The theoretical implication of the study is the contribution to knowledge and literature as crowdfunding is still an emerging issue with less related research. 


\subsection{Historical Background of Crowdfunding}

Crowdfunding has been in existence for the last decade. In 1884, the owner of the firm, Joseph Pulitzer Company, approached the public to raise funds for the construction of a pedestal for the Statue of Liberty in the port of New York with a donation of $£ 1$ or less, in which Pulitizer raised more than $£ 100,000$ in six months from 125,000 individuals (Collins, 2014).In the modern-day phenomena, crowdfunding can be traced to Microfinance and microcredit operation, Crowdfunding is the fusion of two concepts crowdsourcing and microfinance. The objective of microfinance is for the eradication of poverty among the public within a society by ensuring finance is made available to individuals who could not have access to the bank loan. Crowdfunding started from the music and film industries in the developed world. This is in line with private sponsorship and donations that favor the arts and culture. The concept gained popularity in 2009 with the creation of a popular crowdfunding platform called Kickstarter, Historical timelines for crowdfunding according to the FSD Africa Report (2017). are as follows, In 2000 Artist Share launches the first crowdfunding platform for creative industries. In 2005 Zopa becomes the world's first peer-to-peer consumer lending platform and Kiva (microfinance lending platform) was also launches. In 2007 Indiegogo was launched in the US as a rewards crowdfunding platform. In 2009 Kick-starter was launched in the US as a rewards crowdfunding platform. In 2011 Peer-2-Peer Finance Association launches in the UK known as Crowd cube being the first equity crowdfunding platform that was launched in the UK. In 2012 UK Crowdfunding Association was launched and President Obama signs JOBS Act. In 2013 UK FCA launches consultation on crowdfunding and Italy (CONSOB) introduces strict equity crowdfunding regulations. In 2014 New Zealand introduces crowdfunding legislation while India launches equity crowdfunding consultation and IPO of Lending Club known as a consumer lending platform. In 2015 Malaysia introduces equity Crowdfunding regulation and Trust Buddy is known as a Swedish lending platform files for bankruptcy due to mismanagement while DFID launches Crowd Power for renewable energy for crowdfunding in developing countries, In 2016 UK HMRC launches 'Innovative Finance Individual Savings Account. Lending Club faces grand jury subpoena for improper financial disclosure, India conducts consultation of online lending regulation, Funding Circle lists SMEs fund for institutional investors, Ezubao, Chinese lending platform, was exposed as \$7.6bn Ponzi scheme. Also in 2016, UK FCA launches first Regulatory Sandboxes was also launch in Singapore, Australia, Malaysia, and Hong Kong, Malaysia 
introduces a peer-to-peer lending framework, China introduces peer-to-peer lending guidelines while FSD Africa hosted an indaba in June 2016 to the discussed potential of crowdfunding for East Africa, Creation of crowdfunding relies on a favorable legal climate. According to Hornuf and Schwienbacher (2017), various countries have enacted legislation to encourage equity crowdfunding to direct its implementation and also to reduce the danger of crowdfunding. France and the United Kingdom had also drafted regulation to guide and control the operation of loanbased crowdfunding. Besides, the first country in the world that proposed equity crowdfunding law as part of the Jumpstart Our Business Startups (JOBS), Act, 2012 in the USA. This was implemented by the Securities and Exchange Commission (SEC) in 2016. Some other countries such as France, Italy, Belgium, Germany, Austria, and the UK had followed these steps but with a different approach but the same similarities. The laws require a crowdfunding issuer to disclose relevant information about the company's activities. In addition to the fund limits that can be invested by each crowdfunded and the sum that can be collected by the issuer within one year, the crowdfunding site also had to be registered with the commission. The essence of this regulation is to minimize crowd risks associated with the type of investments in particular in equity crowdfunding, in terms of fraud risk or risk. Furthermore, Jegelericiute and Valanciene (2015) stipulated that different countries promote crowdfunding using different approaches and some of these approaches are the provision of the appropriate legal framework that enhances transparency and legal funding market places, promotion of crowdfunding platforms with strong social media market and good internet usage enabling environment, promoting an appropriate crowdfunding campaign, proper enlightens on workability concept of entrepreneur and working process to potentials investors. Besides, country promotes crowdfunding using standard and best practices that fit into circumstances prevailing in the respective country In Nigeria, the Securities and Exchange Commission (SEC) suspended crowd-funding operations based on their strong view that the Companies and Related Matters Act (CAMA) 1990 and the Investment and Securities Act 2007 did not accept crowd-funding as alternative sources of funds to be used by small and medium-sized enterprises. While SEC has put all the necessary machinery in place by reviewing the various laws and regulations that govern the operation of crowdfunding in the United States, the United Kingdom, Canada, and other developed nations intending to create the allowed environment and laws that will guide the operation of this innovation of start-up financing 


\subsection{Conceptual review}

Crowdfunding: Crowdfunding is an evolving trend for small, micro, and individual entrepreneurs to raise funds through the internet-dominated platform. The term crowdfunding comes from crowdsourcing, which has been described as the process of obtaining the necessary resources, ideas, or content by seeking feedback from a large group of individuals, in particular through the online community platform (Pekmezovic \& Walker, 2016) Crowdfunding, on the other hand, is a process of fundraising from potential investors, donors or sponsors to finance creative ideas, start-up business or new ventures as a form of turning ideas into business reality. The word crowd in crowdfunding means the people (general public) connected through the internet platform and this might include potentials investors such as banks, individuals, donors, business angels, or venture capital providers. The major difference between crowdfunding and crowdsourcing is what is provided by the crowd. In crowdfunding, the crowd provides the fund while in crowdsourcing, it is the labor that the crowd provides.

Hossain and Oparaocha (2017) defined crowdfunding as an internet-based method of fundraising for creative ideas, projects, or tasks in form of contribution or pledge of money by a large pool of people within a limited time frame. Schwienbacher and Larralde,(2010) stated that entrepreneurs will rely on the internet to directly source for financial help from the general public (the crowd) instead of approaching Financial investors such as business angels, banks, or venture capital funds because of the stringent method of sourcing fund from these channels. This method, called crowdfunding has made possible in seeking capital for the project and specific investments as well as for starting up new ventures. The idea of crowdfunding can be seen as an important part of the idea of crowdsourcing. Crowdfunding seeks to raise money for investment through the use of social networks on the Internet. Crowd funders (those who provide the money) can also, at times, take part in strategic decisions or even have the right to vote. In other words, instead of raising money from a very small group of professional investors, the concept of crowd-funding is to raise it from a large community where each person can contribute a very small sum. As a result, collecting funds by targeting the general public (or the crowd) is the most critical aspect of crowdfunding. Belleflamme, Lambertz, and Schwienbacherx, (2014) see crowdfunding as an open invitation, especially through the internet platform, for capital, either in form of donation or 
payment for future product or service or as a future reward for supported business ideas or specific purposes. Bouncken, Komorek, and Kraus (2015) also see crowdfunding as a means of raising funds from the public especially groups of individuals around the world using internet Based platforms. Collins (2014) claimed that four technical advancements have led to the growth of Crowdfunding, such as the ability to quickly set up a free online site, safe online money transfer services, and reliable credit scores. The three components of crowdfunding include a large number of investors, the distribution of relatively small sums of money from each investor, the use of the Internet, which is used for its convenience, and the ability to link individuals across the globe.

\subsection{Some benefits of crowdfunding}

Crowdfunding offers resources for small and medium-sized companies and innovative to obtain capital that would not have obtained for their operations under normal business conditions (Assenova et al., 2016). The inability of these businesses and individuals to access funds from traditional sources has given rise to many promising ideas for not seeing the light of day. And if promoters of such businesses can midwife it to open doors for companies, it is difficult to achieve sustaining and expanding the operations in the absence of sufficient funding thus undermining the economy of their critical contribution. As traditional investors back out, and in the absence of intervention funds from government agencies and programs, especially now that the country is struggling from the economic recession, SMEs and initiators of creative ideas are compelled to look at alternative sources of funding and consequently tapping into the internet to solicit donations and investible funds become inevitable. The constraints associated with SMEs and creative ideas in the search for the fund are consequent upon the size, asset base, profit prospects, lack of expertise, etc. At best, even if they can secure funding, due to the number of competing firms, the available funds may not be enough to sustain the operations and penetrate further into markets, (Agrawal, Catalini \& Goldfab, 2014). Several researchers argue that crowdfunding is not necessarily linked to monetary benefits (Belleflamme, Lambert, and Schwienbacher, 2011); The investment process promotes product-market testing; Crowdfunding advantages that differentiate it from other conventional sources of funding, including banks and venture capitalists; crowdfunding allows start-ups and developers of creative ideas to manage; the funding strategy leverages the power of the Internet through the use of social media to raise 
funds (BERNDT \& MBASSANA, 2016). As a marketing tool, it offers an incentive for the developers of a product to publicly test it for its final implementation. Crowd financing promotes direct customer engagement (Younkin and Kashkooli 2016). D'Entremont (2013) while studying early start-up crowdfunding in Canada, campaigners interacted with those who have to say, "Crowdfunding does three things for us. It allows us to validate the business model, it allows us to market our product, and it allows us to raise capital." To others, "This is also a way for people to get involved and feel a connection with our brand and the product." While these authors are correct about the phenomenon called crowdfunding, associated ethical concerns or risks ranging from exposure to fraudulent campaigns, lack of privacy, and abuse of funds raised (Snyder, Mathers, and Crooks 2016; Leela, 2016) It is widely acknowledged that SMEs occupy a pivotal role in the development of any economy, with potentials for employment generation, entrepreneurship development, product diversification, market penetrations, and forward integration with large-scale industries. In Nigeria, SMEs are known for gross underperformance resulting from key issues such as unfriendly business environment, poor funding, low managerial skills, and lack of access to technology; poor funding is the most central of all. The reason is that money deposit banks which remain the major source of funds to SMEs are no longer willing in their role due to the high risk and uncertainties. In Nigeria, SME entrepreneurs and initiators of creative ideas face a lot of funding challenge is no longer news. However, Ariyo (2000) argues that the challenges they face are due to their inability to recognize alternative funding sources. This lack of awareness is further compounded as conventional fund managers grow increasingly uncertain about the future of these companies and individuals. The position of this paper is that SMEs and developers of creative ideas and projects will raise money for product creation, promotion, and expansion of crowdfunding operations, in line with Belle Flamme, Lambert \& Schwienbacher (2014); the authors think that crowdfunding would allow companies to launch a new product, check the acceptability of products, etc.

\section{4 Models of Crowdfunding}

Recent work on crowdfunding as cited in Soreh (2017) by Massolution (2015) suggests varied models such as donation-based, reward-based, equity-based, loan-based, pre-order, and hybrid models. Donation and reward-based funding is known as community / non-financial crowd financing whereas equity and peer-to-peer loans are called financial crowdfunding 
- Donation-based model: This is a crowdfunding strategy in which the campaigner seeks in the public (crowd) for a small fund in the form of donations from various individuals. The aim of this is to help finance a project or ideas without the donor's anticipated reward. This is a way of donating money to help a specific cause or project such as an educational program, drought, and relief from disasters. The financial supporter's only reward derivable is the pleasure he/she gets in contributing to a worthy cause as the project continued to succeed and do well in the market as the initiators had expected, Example of these Types are JustGiving (http://www.justgiving.com), Go Fund Me (http://www.gofundme.com)

- Reward-based model: It's a non-monetary reward from the donor. It is a form of solicitation of financial support from the crowd in return for tangible or non-tangible items. Tangible rewards may be in the form of cloth, equipment, machinery, or company products, while non-tangible rewards may be in the form of personal thank you, advertising the name of the donor, displaying the name of the donor on the project, or recognizing the donor as a supporter of the project. Examples are Kickstarter (https://www.kicksterter.com) and Indiegogo. (https://www.indiegogo.com).

- Equity-based model: This model of crowd-funding involves a campaigner inviting the general public to invest in a project or creative ideas in return for an ownership interest. The model is fast becoming an important means of financing small and medium-sized enterprises in the United Kingdom and the United States with good legislation. A backer/fund supporter receives an equity interest in the company in return for their donation, which enables them to participate in the sharing of future profits generated by the project. According to Soreh (2017), the World Bank has estimated equity crowdfunding at $£ 90$ billion by 2020 but this could be achieved seriously as a result of the trend in this financing model. An example is Peer Realty (http://www.Peerrealty.com).

- Loan based model/ Peer to Peer lending (P2P): It also referred to microfinance or peer lending. It is a form in which contributors see their fund as a loan to attract interest payments at maturity, or crowdfund have contributed to the pool for SMEs to raise funds 
in the form of debt finance. Massolution (2016) argued that, in 2015, GBP 25 billion was raised through crowdfunding using the approach of debt contracts. Peer-to-peer lending is very common in countries where it is difficult to get a bank loan to start a business. There are different lending club locations for a loan model based on crowdfunding in developed countries, where investors make returns to contributors in the form of interest, although the risk associated with it is very high in some countries like Malaysia, there is B2BFinPal

(http://www.b2bfinpal.com).

- Product pre-order model: The campaigner sells his product at a very cheap price in return for a pledge. The backer supporters are those that pledge for the product. It achieves the aim of ensuring the campaigners the opportunity of returning the money raised to the contributors.

- Hybrid model: This form of model offers more than one approach at a time. According to Abushaban (2014), it is a campaign for capital as a loan as well as a pledge. In the form of capital, the platform focuses on business start-ups which allows the contributors to co-invest in the project in the form of venture capital. The major characteristic of crowdfunding is that creative ideas initiators need to supply detailed information about the ventures to the general public through the internet as a means of convincing investors to contribute. The essence of this is to reduce information asymmetry, fraud, and risk associated with the venture to the investor.

\subsection{Small and Medium Enterprises (SMEs)}

As in developed economies, Nigeria has tackled the question of the definition of what constitutes small and medium-sized enterprises with the adoption of the National Policy on Small and Medium-sized Enterprises. The term shall follow a classification based on dual criteria, jobs, and properties (excluding land and buildings)

Small and medium-sized enterprises are those companies whose total assets (excluding land and buildings) are less than 5 million Naira employees with a workforce not exceeding $10 \mathrm{~m}$. Small Enterprises are those enterprises whose total assets (excluding land and building) are above Five Million Naira but not exceeding Fifty Million Naira with a total workforce of above ten, but not 
exceeding forty-nine employees. Medium Enterprises are those enterprises with total assets excluding land and building) are above Fifty Million Naira, but not exceeding Five Hundred Million Naira with a total workforce of between 50 and 199 employees. If there exists a conflict on classification between employment and assets criteria (for example, if an enterprise has assets worth seven million nairas (N7M) but employs 7 persons), the employment-based classification will take precedence and the enterprise would be regarded as SMEs.

In Nigeria, the National Bureau of Statistics (2015) identified small and medium-sized enterprises based on three classifications, such as micro-enterprises with a workforce of less than 10 and assets (excluding land and buildings) of less than 5 million, small enterprises with a workforce of between 10 and 49, while assets (excluding land and buildings) of between 5 million and 50 million. The third classification is medium-sized businesses with a workforce of between 50 and 199 workers with assets of value (excluding land and buildings) ranging from 50 million to 500 million.

The Central Bank of Nigeria (CBN) defined SMEs based on small scale business with total assets value (excluding land and building) of less than million with less than 50 employees while the medium scale business are those with assets value (excluding land and building) of less than $\$ 50$ million with a

Staff strengths of between 50 and 100 employees According to Gbandi and Amissah (2014) SMEs in the United Kingdom have been categorized as a company with a sales volume of fewer than 200 million pounds and a staff strength of less than 200, while small and medium-sized businesses in Japan have a sales turnover of not more than 100 million yen with a staff strength of not more than 300 workers. Ayozie, Oboreh, Umokoro, and Ayozie (2013) reported that, in the USA, small and medium-sized enterprises are considered to be independently owned businesses run and financed by small groups of people with staff strength of up to 1500 , depending on the form of industry.

Central banks, merchant banks, and development banks are the traditional provider of finance to small and medium-sized enterprises, but in recent times, these banks have been reluctant to provide funds to small and medium-sized enterprises. Small and medium-sized enterprises are seen to play a pivotal role in the development of many countries ' economies through the generation of jobs, economic growth, and development of entrepreneurship and product creation. 
Based on this, most governments around the world are concentrating on the creation of the small and medium-sized enterprises sector to promote economic growth and social development. Besides, SMEs in Asian countries such as Malaysia, India, and China had contributed to the economic growth and development of such countries. According to Gbandi and Amissah (2014), SMEs in India accounted for 39 percent of manufacturing output while SMEs accounted for 33 percent of the country's total exports even with government support for development, a favorable climate, and a good regulatory structure, finance still presents challenges to many small and medium-sized enterprises and innovative ideas for starting a company in these countries and around the world (Najah \& Jarboui, 2015). Small and medium-sized enterprises ( SMEs) are expected to be used by the responsive government as a significant tool to resolve the challenges of job creation, sustainable economic growth, equal income distribution, and the overall stimulation of economic development (FinScope, 2010). According to the Organization for Economic Cooperation and Development (2014), small and medium-sized enterprises (SMEs) are crucial for forming new pathways to more sustainable and inclusive growth in the economy because of their position in developing and dispersing innovation and providing jobs for the employable citizen. In the sense of this paper, the concept of small and medium-sized enterprises by CBN will be adopted as it represents over 80 percent of Nigerian enterprises.

\subsection{Crowdfunding in Nigeria}

Given the achievements of crowdfunding as a financing solution elsewhere, the tool is snailspeed entering the country's entrepreneurial finance. There is currently no existing database for crowdfunding activities in the region. For the time being, no current laws are governing its application for entrepreneurial activities in the country and they are unlikely to be short. Perhaps this is the underlying reason why the most active crowdfunding projects in Nigeria are the social causes. Virtually, most of the successful campaigns are to help the sick (health-related). Instead of using established crowdfunding platforms or site, campaigners use the electronic media, especially Television stations, with a designated bank account. A review of successful campaigns for entrepreneurial purposes reveals that one of such campaigns on one of the Nigerian-oriented sites was funded by the promoters of the platform. Thereafter, there is no indication of other successful campaigns for over four years leaving the first successful campaign a suspect. This does not mean that the concept is not workable in the country but triggers regulatory concerns, 
(Assenova, et. al 2016). Nigeria is said to be a host of about nine (9) crowdfunding platforms with several listings on some of the platforms, especially indigenous sites such as Imeela, Naturfund, Funmilowo, Donate-ng, but there is little or no evidence of successful funding for entrepreneurial activities. The one or two successful campaigns recorded for entrepreneurial activities in the country were listed on Kickstarter and Indiegogo; incidentally, the campaigners are not Nigerians. On the other hand, the government is not doing enough to fund innovation in the country. Instead of enacting the requisite regulations to ensure that it is enforced by the Securities and Exchange Commission (SEC), the government has raised further doubts about the definition by claiming that the Commission does not endorse crowdfunding because of certain provisions in CAMA 1990 as amended and ISA 2007. The stance of the government may be accurate to some degree because, without supervision, violations are likely to be rampant. Abushaban (2014) argues that developing countries, particularly in the Middle East and Africa, can benefit greatly from Crowdfunding, especially in the face of funding challenges for small and medium-sized enterprises and innovative creative ideas, as the approach is capable of having the desired positive impact on these disadvantaged societies. Prompt action with a policy on best practice and subsequent relevant legislation will help to minimize such shady transactions that would further dampen the concerns of potential sponsors, speed up the process of awarenessraising to leverage the potentials associated with the funding mechanism.

\section{- PROS}

The problem of raising funds from small and medium-sized enterprises and the initiators of innovative ideas and the various strict policies developed by banks to finance start-ups has led to the emergence of crowdfunding. Some of the pros are:

- It provides an opportunity for social interaction and individual connection for the future benefit

- It reduces the cost and time required to raise funds as through the social media platform millions of individuals could be reached all over the world and the projects can be seen and appraise.

- It often much simpler fundraising alternatives. 
- It measures the marketability of projects at an early stage by reaching the accredited investors who intend to invest.

- It created an opportunity for new portfolio investors as documents and other related information relevant to the project are kept online for investors peruse and decision making.

- It enhances fundraising without giving up a large portion of equity interest in SMEs

- It enables risks to be spread to potential investors.

- It leads to the creation of a job through projects funded and its economic added value.

- It builds and enhances project awareness even before the completion of the project.

\section{- CONS}

Crowdfunding is an online forum for collecting small and medium-sized businesses funds from potential crowd investors is a new concept in the world. It faces enormous Cons, such as:

- SMEs inability to compensate or return investors fund where the platform operator does not guarantee the success of the project (Bergamini, Navarro \& Hilliard, 2017)

- Lack of proper evaluation of risk and value of projects

- Lack of appropriate skills by crowd investors in assessing risk and value of projects

- Challenges of asymmetry of information between fund contributors and creative ideas initiators.

- Risk of cyber-attacks or online fraud due to online payments by investors who lack secrecy.

- Risk of default by SMEs on the crowdfunding platform due to the sudden closure of the crowdfunding Platform thereby leaving the investors and borrowers at a loss

- Raising a huge sum of money through equity crowdfunding can lead to money laundering.

- Risk of liquidity as the capital market for investors fund becomes non-available when compared to other forms of traditional sources of finance for SMEs.

- Lack of specific disclosure requirements by SMEs by law as compared with publicly quoted companies. 
- Risk of ideas being stolen or lost when revealed to investors which can be replicated and executed by other parties.

- Lack of means to protect ideas by SMEs through patents and rights.

\subsection{Theoretical review}

There are different theories in Crowdfunding. Some of the theories are social exchange theory, technology acceptance model, and Johari Window Model

- Social exchange theory: Social exchange theory proposes that social behavior occurred as a result of the exchange process. The essence of this exchange for an individual is to maximize benefits and minimize costs. The theory stipulates that individuals weigh the potential benefit against the risk associated with the social relationship (Rusbult, 1963). Homans (1958) stated that during the period of social interaction, the type of merchandise exchange is the various social behaviors of individuals. Interaction is synonymous with social behavior where an action carried out by one person is rewarded or punished based on the action undertaken by another person, therefore irrespective of the action behavior, it could be stated that the two people surely interact. This interaction reward could either be tangible or intangible. The higher the individual's compensation than the interaction cost, the better for continuous interaction whereas if the interaction cost is higher than the compensation value, the individual will stop the interaction (Organ \& Konovsky, 1989). The theory can be used to explain the cost/benefit analysis in respect of online activities engaged by users. In crowdfunding, promoters may trade off the perceived advantages such as innovative products and sharing ideas against the perceived costs such as product quality which does not meet expectations, delayed product delivery, and patent infringement which affects their attitude, trust, and commitment toward crowdfunding projects. Homans (1958) posits that communication and trust are the basis of interaction models between people by which the social exchange theory postulates. The study uses social exchange theory to explain exchange behaviors between individuals and groups by considering crowdfunding promoters as individuals and new entrepreneur teams as 
groups, whereby mutual communication, trust, and commitment are established through crowdfunding platforms to facilitate social exchange behaviors and benefit

- Technology Acceptance Model (TAM): Fred D. Davis in 1985 proposed Technology Acceptance Model (TAM) through his doctoral thesis at Massachusetts Institutes of Technology (MIT), USA. He anchored on the previous work of Fishbein and Azjen (1975) who formulated the theory of reasoned action. The model was designed to show how individuals accept and make use of technology in decision making. The theory is based on how users faced the challenges of new technology. The decision to adopt this new technology depends on three factors and these are perceived usefulness, perceived ease to use, and individual attitude towards usage. Davis (1986) stated that perceived usefulness is based on individuals' belief that technology will enhance activity performance, perceived ease to use is the individual belief that technology will enhance freedom from physical effort whereby technology is seen as an alternative better option than its substitutes. Besides, perceived usefulness and perceived ease to use is seen to drive the attitudes toward the usage of technology in decision making which is a determinant factor in accepting technology

- Johari Window Model: The Johari Window Model, derived from the work of Joseph Luft and Herry Ingham (1955), is an excellent graphic depiction of the relationship between individuals and self-understanding. Luft and Ingham named this Jahari model after quick names, Joe and Harry; it's named a window because of its four quadrants. It's often referred to as a self-awareness disclosure or input model, and some people call it an information-processing tool.

The Johari window represents information-feeling, experience, views, attitudes, skill, intentions, motivation, etc. Within or about a person about group .it is widely used to understand self, to achieve personal development, improve communications, interpersonal relations, group dynamics, team development, and finally to strengthen inter-group relations.

This study uses the Johari window model to explain individual or group intentions before considering crowdfunding. Feedback, trust, improve communication is to be established through a crowdfunding platform to facilitate interpersonal relationship amongst individual and groups. 


\subsection{Empirical review}

This study builds upon knowledge gained in the previous study by various scholars. Fatoki (2014) in the study financing options for new small and medium enterprises in South Africa concluded that new SMEs are vital to solving the problem of high rates of poverty and employment in South Africa. The failure rate of new SMEs is very high due to a lack of funding by banks. The study suggested that one of the alternative means of sourcing for a fund by SMEs is crowdfunding while the government should provide a good regulatory environment that will enhance the operation and management of crowdfunding. Wang and Chen (2016) in the study determinants of backers funding intention in crowdfunding: Social exchange theory and regulatory focus concluded that crowdfunding had turned out to become a popular financing channel worldwide but rather the success rate of a crowdfunding project is less than $50 \%$. The study suggested that projects proponent should not only attract more visitors but to understand funding intention which leads to the success of the fundraising project. Furthermore, Golic (2013) studies the advantage of crowdfunding as alternative sources of finance for SMEs. It was concluded that crowdfunding serves as alternative sources of financing new small businesses that will enhance the country's GDP while Paschen (2017) reported that crowdfunding has a role to play as a means of enhancing business start-up capital.

Mollick (2013) in the study the dynamics of crowdfunding: An exploratory study concluded that crowdfunding allows the founder of ventures to fund their effort by sourcing funds from a large number of individuals (crowd) using the internet without any standard financial intermediaries. The study suggested that personal networks and underlying project quality are associated with the success of crowdfunding and that environmental and business geography is very relevant to project proposed and fundraising success. Also, Anthony and Harry (2015) in the study SMEs firm performance financial innovation and challenges concluded that SMEs have become a pivoting force of sustained, rapid, and healthy development of Nigeria's economy. The study suggested that one of the ways of improving SMEs in Nigeria is to increase and improve financing provided through crowdfunding. Furthermore, Soreh (2017) also stated in the study of awareness and attitude towards crowdfunding in Nigeria, that the new

Funding innovation is yet to be appraised by an entrepreneur as a new form of finance. This is because crowdfunding awareness is very low at $24 \%$ as reported by the respondents while most 
of the respondents cannot identify any crowdfunding operating in Nigeria. The study suggested that crowdfunding is a possibility in Nigeria if people become more positive regarding the concept and having attitudinal change toward it as a means of funding SMEs and innovation ideas. This was also corroborated by Iddris (2019) on the role of crowdfunding in promoting microenterprises innovation, and thereby stated that crowdfunding awareness is key to being accepted as sources of finance for financing reactive ideas.

Munyanyi and Mapfumo (2016) in the study factors influencing crowdfunding plausibility in post-Hyperinflationary Zimbabwe concluded that crowdfunding is viable alternative means of financing entrepreneurship in Zimbabwe at the time of the hyperinflationary period. Also, Barbi and Bigelli (2017) reported that with the advent of crowdfunding becoming popular and growing in usage for a financing start-up business, it might become the main source of financing new and existing businesses shortly. Furthermore, Berndt (2016) studied crowdfunding in the Africa context and concluded that there are few numbers of users appraising crowdfunding while information about it remains scanty. Also, Suhali and Palil (2016) in the study crowdfunding with waqf based reported that crowdfunding is still at the infancy stage with less emphasis for discussion by academicians. The study concluded that waqf as a powerful instrument for community development should embrace crowdfunding technology for fundraising. In line with this, Yu et al (2017) recognized the crowdfunding campaign as a mechanism of promoting business growth and development through alternative sources of finance.

\subsection{Research Questions}

Crowdfunding is a financing tool that is booming in several countries, but neither the government nor the Nigerian people are making any headway with this idea. Research is therefore designed to assess and quantify people's awareness and attitude to the idea. In light of the above, the purpose of this study is to

Replies to the following questions:

- To what extent are Nigerians aware of crowdfunding as a funding mechanism for SMEs and creative ideas? 
- What is the people's attitude towards crowdfunding as a means of raising money for both businesses and creative ideas?

- Are Nigerians ready to actively participate in crowdfunding campaigns?

\subsection{Methodology}

The study used an exploratory research design, according to which the related literature in the area of business administration, accounting, finance and relating to the subject matter has been reviewed, conclusion Drawn and made a suggestion

\subsection{Summary and Conclusion}

The key findings of this study include crowdfunding as a way of financing innovation for small and medium-sized companies, but in Nigeria, it is at a snail pace. Crowdfunding activities are as poor as $1 \%$ based on information obtained from internet users. Crowdfunding is generally known in Nigeria as a social cause as most of the successful projects were aimed at helping the disabled, although the presence of Nigerian-oriented platforms still has no major effect on the promotion of crowdfunding for small and medium-sized enterprises. This may be due to the failure of the networks to create the need for trust between the Internet user and social media followers.

The potential for crowdfunding is immense, but there is a need for a strong political will to encourage and increase public awareness, and until then the funding mechanism will not be able to unleash its capacity to grow small and medium-sized enterprises in Nigeria. It is assumed that if there is a right alignment between stakeholders and the right strategy is used to inform the public about what the financing process is all about, its advantages, and risks. Nigeria's approach to the idea will radically change for good, as there is an eagerness on the part of internet users or the general public to engage in potential crowdfunding projects, either as a sponsor or fundraiser that points to the potential of crowdfunding in Nigeria, but there is no guarantee about the future of crowdfunding in Nigeria in the immediate future due to the regulatory position of Nigeria. Nigeria Securities and Exchange Commission (NSEC) Hope is not lost as more and more groups 
begin to see what innovation funding is capable of taking finance to small and medium-sized enterprises in Nigeria. It is not to suggest that there will be no mistakes and losses, but with seminars and experiences, knowledge and perceptions will change for the better, and crowdfunding will overcome many of its problems as strategies and regulations begin to shape the sector. It is doubtful that the rewards of crowdfunding will go around all sorts of projects and creative ideas, but it will help bring many projects and ideas to life that wouldn't have to see the light of day.

\subsection{Results}

Since crowdfunding has to do with someone seeks financial assistance from the public and people making individual donations for a small amount of money for a specific purpose. Public or internet users were asked to have any information on social media in Nigeria about a person or group of people doing such a campaign. One hundred percent of the population says they have learned of such promotions. Although 45 percent did not donate online either to support the sick or anybody with a business idea, the result is an indicator of Nigeria's bad habit of making online donations to benefit one another. From the results capturing from public or internet users, but even though a significant number of public / internet users have read or heard about the concept and have come to believe that it is a funding mechanism, they have no complete understanding of how the concept works. The position puts potential campaigners at a crossroads unless they take the extra mile to educate potential funders. Alongside the funder seeker, crowdfunding platforms have a role to play in creating an awareness team if they are to achieve the goal of establishing such a platform. The greater the public's confidence in the platform projects listed on it is likely to attract a wider audience, as more and more people come to have a good understanding of the concept and how small and medium-sized enterprises finance is shaping in the developed world, and the more time it is in Nigeria, the better it is for the country to move into a nation-wide committee to explore potentials. 


\section{REFERENCES}

Agrawal, A., Catalini, C., \& Goldfarb, A. 2014 some simple economics of crowdfunding, NBER Working Paper, Innovation Policy and Economy 14

Ariyo, D. 2000. Small firms are the backbone of the Nigerian economy. African Economy Analysis, Available at http://www.afbis.com/analysis/small.htm (December, 62018 )

Assenova, et. Al., (2016) 'The future of crowdfunding', California Management Review: 58 (2); Pp. $125-135$

Anthony, E. A., \& Harry, O. P., 2015, Crowd funding, Journal of African and Asian Studies, 12, $10-24$

Ayozie, D. U., Oboreh, S. L., Umokoro, F., \& Ayozie, V. U. 2013, Small and Medium Scale Enterprises (SMEs) in Nigeria: The marketing interface. Global Journal of Management and Business Research Marketing, 13(9), 1-13

Abushaban, R. M. 2014. Crowdfunding as a catapult for innovation in the Middle East: Obstacles and possibilities. Global Humanitarian Technology Conference, San Jose, USA

Bouncken, R. B., Komorek, M., \& Kraus, S. (2015). Crowdfunding: The current state of research. The International Business and Economics Research Journal, 14(3), 407

Belleflamme, P., Lambert, T., and Schwienbacher, A. (2011) 'Crowdfunding: Tapping the right crowd', Center for Operations Research and Econometrics (pp. 1-37): (CORE).

BERNDT, A. \& MBASSANA, and M. (2016) 'Crowdfunding: the beliefs of Rwandan entrepreneurs ', East Africa Research Papers in Business, Entrepreneurship and Management: Available at http://ju.se/download/18.b50f80815532427699617f/1465522955791/EARP-BEM+2016 05+Adele.pdf

Belleflamme, P., Lambert, T. \& Schwienbeacher, A. (2014), Crowdfunding: Tapping the right crowd. Journal of Business Venturing, 29(5), 585-609 
Barbi, M., \& Bigelli, M. 2017 Crowdfunding practices in and outside the US, Research in International Business and Finance, 42(7), 208-223

Bergamini, T. P., Navarro, C. L., \& Hilliard, I. (2017). Is crowdfunding an appropriate financial model for social entrepreneurship, Academy of Entrepreneurship Journal, 23(1), 44- 57?

Berndt, A. (2016). Crowdfunding in Africa context: A new way to fund ventures. Entrepreneurship and SMEs Management across Africa, 31-49

Collins, A. A. (2014). Crowdfunding as a source of finance, Journal of Entrepreneurship and Business Innovation, 4(1), 16-30

d'Entremont, Y. (2013) ‘Crowdfunding: does it really work?’ Nova Scotia Business Journal

Davis, F. D. (1986) Technology acceptance model for empirically testing new end user information theory and results, unpublished doctoral dissertation. MIT

Fishbein, M., \& Ajzen, I. (1975). Belief, intention and behavior: An introduction to theory and research, Reading, MA: Addison Wesley

Fleming, L., \& Sorenson, O. (2016). Financing by and for the masses: An introduction to the special issue on crowdfunding. Califonia Magazine Review, 58(2), 5-19

Fatoki, O. (2014). The financing options for new small and medium enterprises in South Africa. Mediterranean Journal of Social Sciences, 5(20), 748-759

FinScope, (2010).South Africa small business survey (Online). Available:http://www.btrust.org.za/downloadfinscope small business survey final report march 2011, (December 5, 2018)

Golic, Z. (2014). Advantage of crowdfunding as an alternative sources of financing of small and medium sized enterprises. Proceeding of the Faculty of Economics in East Sarajevo, 8, $39-48$

Gbandi, E. C., \& Amissah, G. (2014). Financing option for small and medium (SMEs) firms Nigeria, European Scientific Journal, 10(1), 327-340 
Hornuf, L., \& Schwienbacher, A. (2016). Crowdinvesting Angel investing for the masses? In. C. Mason and H.Landstron (Eds). Handbook of Research on Business Angels, 381-397. Edward Elgar Publishing

Hossain, M. (2015). Crowdfunding in business and management disciplines an integrative literature review. Journal of Global Entrepreneurship Research, 5(21), 1-19

Hossain, M., \& Oparaocha, G. O. (2017). Crowdfunding: Motives, definition, etymology and ethicalchallenges.EntrepreneurshipResearchJournal.Availableat:http://www.researchga e.net/publication/311065516. (February 10, 2019).

Homans, G. C. (1958). Social behavior as exchange, American Journal of Sociology, 63, 597 606

* Iddris, F. (2019). The role of crowdfunding in promoting innovation in microenterprises in Africa, University of Cape Coast College of humanities and legal studies, School of economics, 10th Microfinance conference, 7-8 February, 2019

Jegelericiute, S., \& Valanciene, L. (2015) Comparative analysis of the ways crowdfunding is promoted. 20th International Scientific Conference Economics and Management 2015(ICEM-2015), 268-274. Procedia-Social and Behavioral Sciences. https:// doi. org/ 10.1016/j.sbspro.2015.11.536.

Kazure, M. A., \& Abdullah, A. R. (2018), Crowdfunding as financial option for Small and Medium Enterprises (SMEs) in Nigeria, Pertanika Journal of Scholarly Reviews, 4(3), $89-96$

Munyayi, W., \& Mapfumo, A. (2016), Factors influencing crowdfunding plausibility in post hyperinflationary Zimbabwe. Journal of Entrepreneurship and Business Innovation, 3(1), $18-28$

Massolution, (2015). Global crowdfunding market to reach $£ 34.4 \mathrm{~B}$ in 2015 , Available at http://www.crowdsourcing.org/editorial/globalcrowdfundingmarket-to-reach-34.4b-in 2015-predictsmassolution-2015ef-industry-report/45376 (access on December 5, 2018) 
Mollick, E., (2014). The dynamics of crowdfunding: Anexploratory study. Journal of Business Venturing, (29(1), 1-16

Nordin, N., Md. Sum, R., \& Zainuddin, Z. (2018).Crowdfunding: Threat or opportunity. Paper presented at the conference towards livable, resilient and competitive cities international conference 2018, Kaula Lumpur,Malaysia, University of Malaysia. Retrieved April 04, 2019.

Najah, A., \& Jarboui, A. (2015). Crowdfunding for financing innovative and social entrepreneurship: Literature review. Journal of Business Management and Economics, 3(6), 21-24.

Organ, D. W., \& Konovsky, M. (1989). Cognitive versus affective determinants of organizational citizenship behavior. J. Appl. Psychol, 74(1), 157-164

Paschen, J. (2017). Choose wisely: Crowdfunding through the stages of the start-up life cycle. Business Horizons, 60(2), 179-188

Pekmezonic, A., \& Walker, G. (2016). The global significance of crowdfunding: Solving the SME funding problem and democratizing access to capital. William and Mary Business Law Review, 7(2). 349- 371

Rusbult, C. A. (1963). A longitudinal test of the investment model: The development and deterioration of satisfaction and commitment in heterosexual involvements. Journal of Personality and Social Psychology, 45, 172-186

Soreh, W. C. (2017). Awareness and attitude towards crowdfunding in Nigeria, International Journal of African and Asian Studies, 36, 1-8

Schwienbacher, A., \& Larralde, B, (2010) Crowd funding of Small Entrepreneurial Venture in: The Oxford Handbook of Entrepreneurial Finance, New York: Oxford University Press

Suhaili, N. A., \& Palil, M. R. (2016). Crowdfunding: A collaborative Waqf based internet platform. International Journal of Business, Economics and Law, 11(5), 41-46ysis. Available at http://www.afbis.com/analysis/small.htm. (December, 6 2018) 
Suhaili, N. A., \& Palil, M. R. (2016). Crowdfunding: A collaborative Waqf based internet platform. International Journal of Business, Economics and Law, 11(5), 41-46

Wieck, E., Bretschneider, U., \& Leimeister, J. M. (2013).Funding from the crowd: An internet based crowdfundingplatform to support business set-ups from universities. International Journal of Cooperative Information System, 22(3), 1-21

Yu, S., Johnson, S., Lai, C., Cricelli, A., \& Fleming, L. (2017). Crowdfunding and regional entrepreneurial investment: An application of the Crowd Berkeley database. Research Policy, 46(10), 1723-1737

Younkin, P \& Kashkooli, K. (2016) 'What problems does crowdfunding solves, California Management Review, Vol. 58 (2), Pp20-43. 